\title{
PENGARUH KUALITAS PRODUK, CITRA MEREK DAN CELEBRITY ENDORSER TERHADAP KEPUTUSAN PEMBELIAN SHAMPOO SUNSILK PADA INDOMARET WILAYAH PASAR MINGGU JAKARTA SELATAN
}

\author{
Mega Yunita \\ Elwisam \\ Email: megayunita_28@yahoo.com, wisamkrimuk@yahoo.com \\ Program Studi Manajemen Fakultas Ekonomi \\ Universitas Nasional
}

\begin{abstract}
ABSTRAK
Penelitian ini bertujuan untuk menguji dan menganalisis pengaruh kualitas produk, citra merek dan celebrity endoser terhadap keputusan pembelian shampoo Sunsilk pada Indomaret wilayah Pasar Minggu, Jakarta Selatan. Sampel yang digunakan dalam penelitian ini terdiri dari 100 responden. Metode penelitian yang digunakan adalah regresi linear berganda. Hasil penelitian menunjukkan bahwa kualitas produk, citra merek dan celebrity endorser secara parsial berpengaruh positif dan signifikan terhadap keputusan pembelian shampoo Sunsilk.
\end{abstract}

Kata kunci: Kualitas produk, citra merek, celebrity endorser, keputusan pembelian

\begin{abstract}
This study aims to test and analyze the effect of product quality, brand image and celebrity endorser on purchasing decision of Sunsilk shampoo on Indomaret of Pasar Minggu area, South Jakarta. Samples used in this study consisted of 100 respondents. The study method used was multiple linear regression. Results of the study showed that product quality, brand image and celebrity endorser partially has positive and significant effect on purchasing decision of Sunsilk shampoo on Indomaret Pasar Minggu, South Jakarta.
\end{abstract}

Keywords: Quality product, brand image, celebrity endorser, purchase decision.

\section{PENDAHULUAN}

Perkembangan dunia bisnis yang begitu pesat membuat persaingan semakin ketat. Hal ini menyebabkan manajemen perusahaan dituntut untuk lebih cermat dalam menentukan strategi bersaing. Perusahaan perlu menganalisis faktor-faktor yang mempengaruhi keputusan pembelian dan memaksimalkannya agar dapat meningkatkan keputusan pembelian konsumen terhadap barang/jasa yang diproduksinya.

Saat ini, shampoo sudah menjadi kebutuhan sehari-hari. Shampoo tidak hanya digunakan oleh orang-orang dewasa saja, tetapi juga remaja dan anak-anak. Luasnya pangsa pasar shampoo membuat berbagai perusahaan tertarik untuk memasuki industri ini. Banyaknya produsen shampoo menimbulkan persaingan bisnis yang ketat. Akan tetapi, hanya beberapa merek shampoo saja yang berhasil memenangkan persaingan tersebut yang 
dicerminkan dengan pemberian predikat Top Brand. Berikut ini merupakan tabel Top Brand Index shampoo pada tahun 2013-2015.

Tabel 1. Top Brand Index Shampoo

\begin{tabular}{|c|l|c|c|c|c|}
\hline \multirow{2}{*}{ No. } & \multirow{2}{*}{ Merek } & \multicolumn{3}{|c|}{ Top Brand Index } & \multirow{2}{*}{ Predikat } \\
\cline { 3 - 5 } & & $\mathbf{2 0 1 3}$ & $\mathbf{2 0 1 4}$ & $\mathbf{2 0 1 5}$ & \\
\hline 1. & Pantene & $27,3 \%$ & $25,1 \%$ & $21,4 \%$ & TOP \\
\hline 2. & Clear & $23,1 \%$ & $22,5 \%$ & $22,1 \%$ & TOP \\
\hline 3. & Sunsilk & $18,5 \%$ & $16,5 \%$ & $18,2 \%$ & TOP \\
\hline 4. & Lifebouy & $11,4 \%$ & $10,9 \%$ & $9,7 \%$ & - \\
\hline 5. & Dove & $5,5 \%$ & $6,1 \%$ & $8,4 \%$ & - \\
\hline 6. & Rejoice & $5,0 \%$ & $4,8 \%$ & $5,6 \%$ & - \\
\hline 7. & Zinc & $3,7 \%$ & $4,6 \%$ & $4,3 \%$ & - \\
\hline 8. & Head \& Shoulders & - & $2,5 \%$ & $2,6 \%$ & - \\
\hline 9. & TRESemme & - & - & $2,6 \%$ & - \\
\hline
\end{tabular}

(Sumber: Top Brand Award, 2016)

Berdasarkan tabel di atas, produk shampoo yang bersaing di pasaran saat ini antara lain Pantene, Clear, Sunsilk, Lifebouy, Dove, Rejoice, Zinc, Head \& Shoulders, dan TRESemme. Top Brand Index produk shampoo pada tahun 2013 dan 2014 dimenangkan oleh Pantene dan diikuti oleh Clear dan Sunsilk yang di tempat kedua dan ketiga. Adapun Top Brand Index produk shampoo pada tahun 2015 dimenangkan oleh Clear dan diikuti oleh Pantene dan Sunsilk yang di tempat kedua dan ketiga. Shampoo Sunsilk belum mampu mencapai peringkat pertama Top Brand Index pada tahun 2013-2015. Hal tersebut menunjukkan bahwa Sunsilk belum mampu memenangkan persaingan di industri shampoo. Oleh karena itu, perlu dilakukan penelitian untuk menganalisis faktor-faktor yang mempengaruhi keputusan pembelian shampoo Sunsilk.

Menurut Fatlahah (2013:480), kualitas produk memiliki pengaruh yang positif dan signifikan terhadap keputusan pembelian. Produk yang berkualitas tinggi akan mampu memenuhi kepuasan konsumen dan meningkatkan keputusan pembelian terhadap produk itu sendiri.

Hasil penelitian yang dilakukan oleh Wulandari dan Nurcahya (2015:1532) menunjukkan bahwa brand image berpengaruh positif dan signifikan terhadap keputusan pembelian. Hal ini menunjukkan bahwa apabila brand suatu produk memiliki image yang positif dan diyakini dapat memenuhi kebutuhan dan keinginan konsumen, maka keputusan untuk membeli suatu produk tersebut akan timbul dari dalam diri konsumen. Semakin baik citra merek yang melekat pada suatu produk, maka semakin tinggi tingkat kepercayaan 
konsumen terhadap produk tersebut, sehingga semakin tinggi tingkat keputusan pembelian konsumen terhadap produk tersebut.

Celebrity endorser juga berpengaruh positif dan signifikan terhadap keputusan pembelian suatu produk. Hal ini sesuai dengan hasil penelitian yang dilakukan oleh Bramantya dan Jatra (2016). Hal tersebut dikarenakan penggunaan selebriti yang tepat sebagai celebrity endorser dari suatu produk akan menimbulkan rasa ketertarikan di dalam diri konsumen untuk membeli produk tersebut.

Berdasarkan latar belakang tersebut, perlu dilakukan penelitian untuk menguji dan menganalisis pengaruh kualitas produk, citra merek dan celebrity endorser terhadap keputusan pembelian shampoo Sunsilk.

\section{TINJAUAN PUSTAKA}

\section{Keputusan Pembelian}

Menurut Kotler dan Keller (2012:201), keputusan pembelian adalah cara individu, kelompok, ataupun organisasi dimana untuk memilih, membeli, memakai dan memanfaatkan barang, jasa, gagasan serta pengalaman dalam rangka untuk memuaskan kebutuhan hasrat.

\section{Kualitas Produk}

Menurut Kotler dan Amstrong (2011:299), kualitas produk adalah kemampuan produk untuk menampilkan fungsinya, termasuk waktu kegunaan dari produk, kehandalan, kemudahan, dalam penggunaan dan perbaikan, dan nilai-nilai yang lainnya.

\section{Citra Merek}

Menurut Rangkuti (2008:3), citra merek (brand image) adalah sekumpulan asosiasi merek yang terbentuk dan muncul di benak konsumen ketika mengingat sebuah merek tertentu. Menurut Kotler dan Keller (2012:260), mempersepsikan citra merek adalah proses dimana seseorang memilih, mengorganisasikan, dan mengartikan masukan informasi untuk menciptakan suatu gambaran yang berarti.

\section{Celebrity Endorser}

Shimp (2007) mengemukakan bahwa celebrity endorser adalah tokoh yang dikenal masyarakat di dalam bidang-bidang yang berbeda yang dapat mempengaruhi pembelian atas suatu produk karena prestasinya. 


\section{Keterkaitan Antarvariabel Penelitian}

\section{Keterkaitan Antara Kualitas Produk dan Keputusan Pembelian}

Menurut Fatlahah (2013:480), kualitas produk memiliki pengaruh yang positif dan signifikan terhadap keputusan pembelian. Artinya, semakin bagus kualitas suatu produk maka semakin cepat konsumen memutuskan pembelian atas produk tersebut.

$\mathrm{H}_{1}$ : Kualitas produk berpengaruh positif dan signifikan terhadap keputusan pembelian shampoo Sunsilk pada Indomaret wilayah Pasar Minggu, Jakarta Selatan.

\section{Keterkaitan Antara Citra Merek dan Keputusan Pembelian}

Hasil penelitian yang dilakukan oleh Wulandari dan Nurcahya (2015:1532) menunjukkan bahwa brand image berpengaruh positif dan signifikan terhadap keputusan pembelian. Hal ini menunjukkan bahwa apabila brand suatu produk memiliki image yang positif dan diyakini dapat memenuhi kebutuhan dan keinginan konsumen, maka keputusan untuk membeli suatu produk tersebut akan timbul dari dalam diri konsumen.

$\mathrm{H}_{2}$ : Citra merek berpengaruh positif dan signifikan terhadap keputusan pembelian shampoo Sunsilk pada Indomaret wilayah Pasar Minggu, Jakarta Selatan.

\section{Keterkaitan Antara Citra Merek dengan Keputusan Pembelian}

Hasil penelitian yang dilakukan oleh Bramantya dan Jatra (2016) menunjukkan bahwa celebrity endorser berpengaruh positif dan signifikan terhadap keputusan pembelian. Hal tersebut dikarenakan konsumen yang memiliki rasa ketertarikan terhadap selebriti dan merasakan bagian dari selebriti pada iklan tersebut akan terpengaruh untuk membuat keputusan pembelian terhadap merek yang diiklankan tersebut.

$\mathrm{H}_{3}$ : Celebrity endorser berpengaruh positif dan signifikan terhadap keputusan pembelian shampoo Sunsilk pada Indomaret wilayah Pasar Minggu, Jakarta Selatan. 


\section{Kerangka Analisis}

Berikut ini merupakan kerangka analisis dalam penelitian ini.

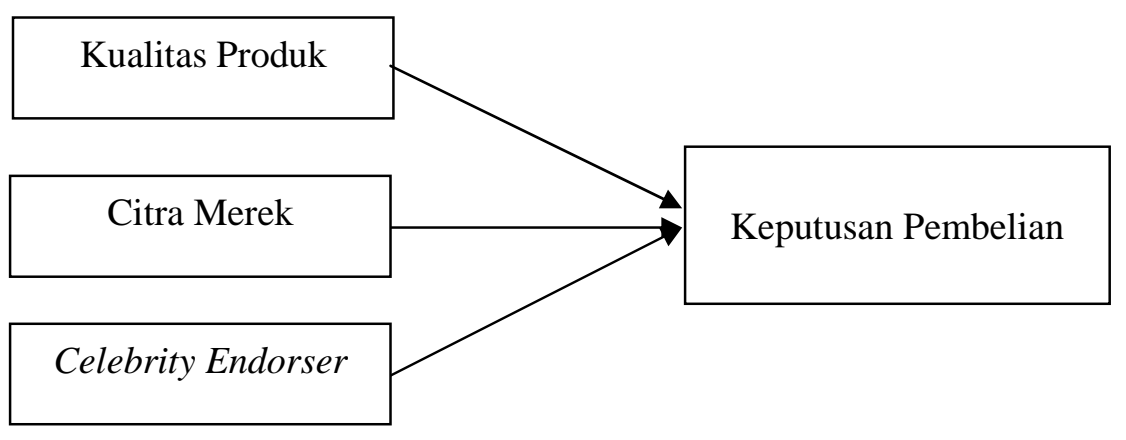

Gambar 1. Kerangka Analisis

\section{METODE PENELITIAN}

\section{Sumber dan Jenis Data}

Jenis data yang digunakan dalam penelitian ini adalah data primer dan cross section yang bersumber dari hasil kuesioner.

\section{Populasi dan Sampel}

Populasi yang digunakan dalam penelitian ini adalah konsumen shampoo Sunsilk pada Indomaret Wilayah Pasar Minggu, Jakarta Selatan. Jumlah sampel yang diambil ditentukan menggunakan rumus Anderson, et al. (2011:364), yaitu sebagai berikut.

$$
\mathrm{n}=\frac{\left(\mathrm{Z}_{\mathrm{B} / 2}\right)^{2} \mathrm{P}^{*}(1-\mathrm{P})}{\mathrm{E}^{2}}
$$

Keterangan:

$\mathrm{Z}_{\mathrm{a} / 2}=\mathrm{Z}$ tabel dengan tingkat signifikansi tertentu

$\mathrm{P}=$ Proporsi populasi yang diharapkan memiliki karakteristik tertentu

$\mathrm{E}^{2}=$ Tingkat kesalahan yang dapat ditolerir

Berdasarkan rumus tersebut, jumlah sampel yang digunakan dalam penelitian ini adalah 100 responden.

\section{Definisi Operasional Variabel}

Berikut ini merupakan definisi operasional dari variabel-variabel yang digunakan dalam penelitian ini. 
Tabel 2. Definisi Operasional Variabel

\begin{tabular}{|c|c|c|}
\hline Variabel & Definisi & Indikator \\
\hline Kualitas Produk & $\begin{array}{l}\text { Keseluruhan ciri dan sifat dari } \\
\text { suatu produk } \quad \text { yang } \\
\text { mempengaruhi kemampuan } \\
\text { produk tersebut } \\
\text { memuaskan } \\
\text { konsumen. }\end{array}$ & $\begin{array}{l}\text { 1. Kesesuaian Produk } \\
\text { 2. Kemudahan Penggunaan } \\
\text { 3. Kelengkapan Produk }\end{array}$ \\
\hline Citra Merek & $\begin{array}{l}\text { Gambaran atas suatu merek di } \\
\text { benak konsumen. }\end{array}$ & $\begin{array}{ll}\text { 1. } & \text { Mudah dikenali } \\
\text { 2. } & \text { Reputasi yang baik } \\
\text { 3. } & \text { Selalu diingat }\end{array}$ \\
\hline Celebrity Endorser & $\begin{array}{l}\text { Tokoh di dalam bidang-bidang } \\
\text { tertentu yang dapat } \\
\text { mempengaruhi pembelian atas } \\
\text { suatu produk karena prestasi dan } \\
\text { popularitasnya. }\end{array}$ & $\begin{array}{l}\text { 1. Credibility (kredibilitas) } \\
\text { 2. Attractiveness (daya } \\
\text { tarik) } \\
\text { 3. Power (kekuatan) }\end{array}$ \\
\hline Keputusan Pembelian & $\begin{array}{l}\text { Suatu tindakan konsumen dalam } \\
\text { melakukan pembelian atas suatu } \\
\text { produk dari berbagai pilihan } \\
\text { yang ada. }\end{array}$ & $\begin{array}{l}\text { 1. Pilihan Produk } \\
\text { 2. Pilihan Merek } \\
\text { 3. Pilihan Tempat }\end{array}$ \\
\hline
\end{tabular}

\section{Metode Analisis}

Metode analisis dalam penelitian ini adalah regresi linear berganda yang bertujuan untuk menganalisis pengaruh kualitas produk, citra merek dan celebrity endorser terhadap keputusan pembelian shampoo Sunsilk pada Indomaret wilayah Pasar Minggu, Jakarta Selatan.

\section{HASIL PENELITIAN DAN PEMBAHASAN}

\section{Uji Instrumen}

Berdasarkan hasil uji validitas, semua butir pernyataan dalam penelitian ini memiliki $r_{\text {hitung }}>r_{\text {tabel }}$ sebesar 0,194, sehingga semua butir pernyataan tersebut bersifat valid. Berdasarkan hasil uji reliabilitas, masing-masing variabel dalam penelitian ini mempunyai nilai cronbach's alpha di atas 0,60, sehingga masing-masing variabel tersebut bersifat reliabel.

\section{Uji Asumsi Klasik}

Berdasarkan hasil uji normalitas, diperoleh asymp. significance (2-tailed) sebesar 0,239 yang lebih besar daripada 0,05 , sehingga semua data berdistribusi normal. 
Adapun hasil uji multikolinearitas menunjukkan bahwa setiap variabel independen dalam penelitian ini memiliki nilai tolerance $>0,1$ dan nilai VIF $<10$, sehingga tidak terjadi multikolinearitas dalam model regresi ini.

Hasil uji autokorelasi menunjukkan bahwa besarnya nilai Durbin-Watson adalah 2,066. Pada tingkat signifikan 5\% dengan jumlah sampel sebanyak $100(\mathrm{n}=100)$ dan jumlah variabel bebas sebanyak $3(\mathrm{k}=3)$, diperoleh nilai $\mathrm{dL}=1,613$ dan $\mathrm{dU}=1,736$. Hal tersebut menunjukkan bahwa model yang digunakan dalam penelitian ini memenuhi kriteria dU < DW $<4-\mathrm{dU}(1,736<2,066<2,264)$, sehingga tidak ada autokorelasi dalam model regresi ini.

Hasil uji heteroskedasatisitas menunjukkan bahwa setiap variabel mempunyai nilai signifikansi yang lebih besar daripada 0,05, sehingga tidak terjadi heteroskedastisitas dalam model regresi ini.

\section{Analisis Regresi Linear Berganda}

Tabel 3. Hasil Regresi Linear Berganda

\begin{tabular}{|l|r|r|r|r|l|}
\hline \multirow{2}{*}{ Variabel } & \multicolumn{2}{|c|}{$\begin{array}{c}\text { Unstandardized } \\
\text { Coefficients }\end{array}$} & $\begin{array}{c}\text { Standardized } \\
\text { Coefficients }\end{array}$ & \multirow{2}{*}{ t } & \multirow{2}{*}{ Sig. } \\
\cline { 2 - 5 } & B & Std. Error & Beta & & \\
\hline (Constant) & 2.548 & 1.238 & & 2.058 & 0.042 \\
Kualitas Produk & 0.361 & 0.089 & 0.369 & 4.040 & 0.000 \\
Citra Merek & 0.204 & 0.089 & 0.231 & 2.290 & 0.024 \\
Celebrity Endorser & 0.210 & 0.089 & 0.213 & 2.365 & 0.020 \\
\hline
\end{tabular}

(Sumber: Data diolah, 2016)

Berdasarkan tabel standardized coefficients di atas, berikut ini merupakan persamaan regresi linear berganda dalam penelitian ini.

\section{Keputusan Pembelian $=0,369 \mathrm{KP}+0,231 \mathrm{CM}+0,213 \mathrm{CE}$}

Keterangan:

$$
\begin{array}{ll}
\mathrm{KP} & =\text { Kualitas Produk } \\
\mathrm{CM} & =\text { Citra Merek } \\
C E & =\text { Celebrity Endoser }
\end{array}
$$




\section{Uji Kelayakan Model}

\section{Uji F}

Berdasarkan hasil uji f, dapat diketahui bahwa tingkat signifikansi sebesar 0,000< 0,05, sehingga $\mathrm{H}_{\mathrm{o}}$ ditolak dan $\mathrm{H}_{\mathrm{a}}$ diterima. Hal tersebut menunjukkan bahwa model yang dikembangkan dalam penelitian ini bersifat layak. Artinya, variabel-variabel yang digunakan dalam model ini mampu menjelaskan model yang dianalisis.

\section{Uji $\mathbf{R}^{2}$ (Koefisien Determinasi)}

Berdasarkan hasil penelitian ini, besarnya nilai koefisien korelasi (R) adalah 0,651 dan koefisien determinasi $\left(\mathrm{R}^{2}\right)$ adalah 0,423 . Nilai koefisien determinasi $\left(\mathrm{R}^{2}\right)$ sebesar $42,30 \%$ menunjukkan bahwa variabel kualitas produk, citra merek dan celebrity endorser memberikan kontribusi sebesar 42,30\% dalam menjelaskan keputusan pembelian, sedangkan $57,70 \%$ sisanya dijelaskan oleh variabel lain yang tidak di analisis dalam penelitian ini.

\section{Pengujian Hipotesis (Uji T)}

Berdasarkan tabel 3, diperoleh hasil pengujian hipotesis sebagai berikut.

1. Nilai $t_{\text {hitung }}$ kualitas produk sebesar 4,040 berada pada nilai signifikan $0,000<0,05$, sehingga $\mathrm{H}_{0}$ ditolak dan Ha diterima. Hal tersebut menunjukkan bahwa kualitas produk berpengaruh positif dan signifikan terhadap keputusan pembelian produk shampoo Sunsilk pada Indomaret Wilayah Pasar Minggu, Jakarta Selatan.

2. Nilai $t_{\text {hitung }}$ citra merek sebesar 2,290 berada pada nilai signifikan $0,024<0,05$, sehingga $\mathrm{H}_{0}$ ditolak dan Ha diterima. Hal tersebut menunjukkan bahwa citra merek berpengaruh positif dan signifikan terhadap keputusan pembelian produk shampoo Sunsilk pada Indomaret Wilayah Pasar Minggu, Jakarta Selatan.

3. Nilai $t_{\text {hitung }}$ celebrity endorser sebesar 2,365 berada pada nilai signifikan $0,020<0,05$, sehingga $\mathrm{H}_{0}$ ditolak dan Ha diterima. Hal tersebut menunjukkan bahwa celebrity endorser berpengaruh positif dan signifikan terhadap keputusan pembelian produk shampoo Sunsilk pada Indomaret Wilayah Pasar Minggu, Jakarta Selatan.

\section{Pembahasan}

Variabel yang memiliki Standardized Coefficient Beta yang paling besar adalah kualitas produk. Hal tersebut menunjukkan bahwa kualitas produk merupakan variabel bebas dalam penelitian ini yang memiliki kontribusi paling besar dalam peningkatan keputusan pembelian shampoo Sunsilk pada Indomaret wilayah Pasar Minggu, Jakarta Selatan. Citra merek ada pada tingkatan kedua yang perlu diperhatikan untuk meningkatkan keputusan 
pembelian shampoo Sunsilk pada Indomaret wilayah Pasar Minggu, Jakarta Selatan. Adapun celebrity endorser ada pada tingkatan ketiga yang perlu diperhatikan untuk meningkatkan keputusan pembelian shampoo Sunsilk pada Indomaret wilayah Pasar Minggu, Jakarta Selatan.

\section{Pengaruh Kualitas Produk terhadap Keputusan Pembelian}

Berdasarkan hasil penelitian, dapat diketahui bahwa kualitas produk berpengaruh positif dan signifikan terhadap keputusan pembelian pada Indomaret Wilayah Pasar Minggu, Jakarta Selatan. Hasil penelitian ini sejalan dengan hasil penelitian yang dilakukan oleh Fathlahah (2013), Mokoagouw (2016) dan Lotulung, et al. (2015) yang menunjukkan bahwa kualitas produk berpengaruh positif dan signifikan terhadap keputusan pembelian. Hal tersebut dikarenakan kualitas produk merupakan keseluruhan ciri dan sifat dari suatu produk yang mempengaruhi kemampuan produk tersebut dalam memuaskan kebutuhan konsumen. Semakin tinggi tingkat kemampuan produk tersebut dalam memenuhi kebutuhan konsumen yang dinyatakan oleh kualitas produk, maka semakin tinggi pula tingkat pembelian yang dilakukan oleh konsumen.

\section{Pengaruh Citra Merek terhadap Keputusan Pembelian}

Berdasarkan hasil penelitian, dapat diketahui bahwa citra merek berpengaruh positif dan signifikan terhadap keputusan pembelian pada Indomaret wilayah Pasar Minggu, Jakarta Selatan. Hasil penelitian ini sejalan dengan hasil penelitian terdahulu yang dilakukan oleh Wulandari dan Nurcahya (2015) dan Febriyanti dan Wahyuati (2016) yang menunjukkan bahwa brand image berpengaruh positif dan signifikan terhadap keputusan pembelian. Hal tersebut dikarenakan citra merek merupakan deskripsi tentang asosiasi dan keyakinan konsumen terhadap merek tertentu (Tjiptono, 2005:49). Semakin tinggi tingkat keyakinan konsumen atas suatu produk yang dipersepsikan oleh citra mereknya, maka semakin tinggi pula tingkat keputusan pembelian terhadap produk tersebut.

\section{Pengaruh Celebrity Endorser terhadap Keputusan Pembelian}

Berdasarkan hasil penelitian, dapat diketahui bahwa celebrity endorser berpengaruh positif dan signifikan terhadap keputusan pembelian pada Indomaret wilayah Pasar Minggu, Jakarta Selatan. Hasil penelitian ini sejalan dengan penelitian terdahulu yang dilakukan oleh Bramantya dan Jatra (2016) dan Febriyanti dan Wahyuati (2016) yang menunjukkan bahwa celebrity endorser berpengaruh signifikan dan positif terhadap keputusan pembelian. Hal 
tersebut dikarenakan celebrity endorser merupakan tokoh yang dikenal masyarakat di dalam bidang-bidang yang berbeda yang dapat mempengaruhi pembelian atas suatu produk karena prestasinya (Shimp, 2007).

Kontribusi celebrity endorser dalam menjelaskan keputusan pembelian shampoo Sunsilk berada di posisi ketiga. Hal ini terjadi karena Sunsilk tidak mengiklankan produknya segencar merek lain.

\section{KESIMPULAN DAN SARAN}

\section{Kesimpulan}

Berdasarkan hasil penelitian, dapat disimpulkan bahwa kualitas produk, citra merek dan celebrity endorser secara parsial berpengaruh positif dan signifikan terhadap keputusan pembelian shampoo Sunsilk pada Indomaret wilayah Pasar Minggu, Jakarta Selatan.

\section{Saran}

Berdasarkan hasil penelitian, perusahaan perlu mempertahankan dan meningkatkan kualitas dan citra merek shampoo Sunsilk untuk meningkatkan keputusan pembelian masyarakat terhadap shampoo Sunsilk. Perusahaan juga diharapkan dapat meningkatkan penayangan iklan untuk mengoptimalkan penggunaan celebrity endorser dalam rangka meningkatkan keputusan pembelian terhadap shampoo Sunsilk.

\section{DAFTAR PUSTAKA}

Bramantya, Y.B. dan M. Jatra. 2016. Pengaruh Celebrity Endorser dan Brand Image terhadap Keputusan Pembelian Yamaha Jupiter MX di Kota Denpasar. E-Jurnal Manajemen Unud. 5 (3): 1745-1771.

Fatlahah, A. 2013. Pengaruh Kualitas Produk dan Citra Merek terhadap Keputusan Pembelian Es Krim Wall's Magnum. Jurnal Ilmu Manajemen. 1 (2): 472-485.

Febriyanti, R.S. dan A. Wahyuati. 2016. Pengaruh Celebrity Endorser dan Brand Image terhadap Keputusan Pembelian melalui Minat Beli. Jurnal Ilmu dan Riset Manajemen. 5(5): 1-18.

Kotler, P. dan G. Amstrong, 2011. Principles of Marketing. $12^{\text {th }}$ Edition. Pearson Prentice Hall. Terjemahan B. Sabran. Prinsip-prinsip Pemasaran. Edisi 12. Jilid 1. Erlangga. Jakarta.

dan K.L. Keller. 2012. Marketing Management. $12^{\text {th }}$ Edition. Pearson Prentice Hall. Terjemahan H. Teguh, R.A. Rusli dan B. Molan. 2007. Manajemen Pemasaran. Edisi 12. Jilid 2. PT Indeks. Jakarta. 
Lotulung, S.C., J. Lapian., dan S. Moniharapan. 2015. Pengaruh Kualitas Produk, Harga dan WOM (Word of Mouth) terhadap Keputusan Pembelian Handphone Evercoss pada CV Trista Jaya Globalindo Manado. Jurnal Emba. 3 (3): 817-826.

Mokoagouw, M.L. 2016. Pengaruh Gaya Hidup, Harga dan Kualitas Produk terhadap Keputusan Pembelian Handpone Samsung di Mobile IT Center Manado. E-Journal UNSRAT. 16 (1): 493-502.

Rangkuti, F. 2008. Riset Pemasaran. Gramedia Pustaka Utama. Jakarta.

Shimp, T. A. 2007. Integrated Marketing Communication in Advertising and Promotion 7th Edition. Thompson. Ohio. Terjemahan R. Syahrial dan D.A. Sari. Periklanan Promosi Aspek Tambahan Komunikasi Pemasaran Terpadu. Edisi Ke-7. Jilid 1. Erlangga. Jakarta.

Tjiptono, F. 2005. Pemasaran Jasa, Bayumedia Publishing. Malang.

Top Brand Awards. Top Brand Index Fase 1 Kategori Perawatan Pribadi. http://www.topbrand-award.com/index. 19 September 2016 (14:10).

Wulandari, N.M. dan I.K. Nurcahya. 2015. Pengaruh Celebrity Endorser, Brand Image, Brand Trust terhadap Keputusan Pembelian Clear Shampoo di Kota Denpasar. EJurnal Manajemen Unud. 4 (11): 3909-3935. 